\title{
Cilvēciskie mežoṇi: Francs Fanons un rasisms
}

21. gadsimtā rasu skaits variē genētisko un bioloǵisko atklājumu dēḷ. Ir iespējams runāt par 3 rasēm: eiropeīdiem, mongoloīdiem un ekvatoriāliem, vai ar̄ var runāt par piecām kontinentālām rasēm, taču ir iespējams runāt arī par vairākām rasu modifikācijām, uzskaitot katru etniskās piederības variāciju. Tomēr neatkarīgi no tā, cik rasu pastāv un vai rases būšana patiešām ir pamatojama, rase ikdienā bieži tiek identificēta, pamanīta un ievīta ikdienas praksēs un valodas struktūrās.

Rases piesaukšana vai piedēvēšana ir neatṇemama saziṇas un dzīvošanas nepieciešamība, t. i., cilvēkam ir grūti citu cilvēku uztvert kā baltu lapu, neveidojot aizspriedumus, neracionalizējot cilvēka izskatu un izvairoties pievērst pārlieku uzmanību cilvēka ādas krāsai, runas stilam utt. Taču runa vairs nav par rasi. Piesaucot rasi vai cenšoties cilvēku definēt kā "balts, melns, jaukts”, “afrikānis, aziāts” u. tml., svarīgāks ir iemesls, kāpēc šis parametrs ir būtisks, kāpēc ir nepieciešams cilvēkus sagrupēt pēc kāda cilvēku neietekmējama parametra.

Varētu pieṇemt, ka rases identificēšana l̦auj skaidrāk uztvert kultūru daudzveidības. Kultūru daudzveidība īstenojas tiešu un netiešu sabiedrību un iedzīvotāju savstarpējo attiecību rezultātā. Taču daudzveidība netiek pieņemta kā normāla un pieņemama. Pētījumi par pretējo un dažādo drīzāk panāk, ka zināšanas par noteiktām lietām rada ilūzijas (LéviStrauss, 1952, 4), vairoties no noteiktām parādībām: no netīrā, nepatīkamā un nepieṇemamā, un rezultātā slimnieks tiek paslēpts aiz slimnīcas sienām, cietumnieks iesēdināts aiz restēm, dzīvnieks ievietots būrī.

Cilvēks ne tikai izvairās no nenormālā, bet arī cenšas nenormālo ieformēt sev pazīstamos jēdzienos un ikdienas praksēs. Viena no praksēm, ar kuras palīdzību ir iespējams formēt apkārtējos cilvēkus, ir biopolitiskā prakse. Biopolitika raksturo tādu pārvaldības režīmu, kas vieno bioloǵisko un politisko, ekonomisko un sociālo sfēru, lai pārdomātu un pārstrukturētu ķermeṇu autonomiju un k̦ermeṇa (individuālo un grupas) mijiedarbības un spējas. Biopolitika ir diskursīva, procedurāla un tehniska cilvēka dzīves un dzīvības, ķermeṇa un miesas, spēju un iespēju prakse. Rakstā tiks skatīts viens no biopolitikas prakšu paveidiem - ḳermeṇu pārvaldības politika - ciešā saistībā ar rases ideju. 
Ķermeña (nozīmju, izskata, uzturēšanas, dzīvošanas/miršanas) pārvaldības biopolitiskā prakse ir darbību kopums, varas forma, ikdienas gaitas, kas katru cilvēku kā k̦ermeni pakḷauj konkrētam ritmam, izskatam, performancei un normālā aspektam, sakārtojot k̦ermen̦us un to iespēju vērienus. Ķermenis tā dažādajā formā ir nosakāms dažādi - kustības brīvība, mazgāšanās biežums, fiziskās formas uzturēšana, ēšanas paradumi u. tml. Ķermenis nav noteikts, tā nozīmes mainās attiecīgi vēlamajam rezultātam. Lai arī šķietami ķermenis ir fiziska masa, ķermenis ir arī idejas par k̦ermeṇa ideāliem. Nosakot, kurš cilvēks būs piederīgs kādai grupai, tiek skatīta tā forma, kustības, runas spēja, izglītotība, zinātkāre un sabiedriskums. Biopolitika atklāj, kā cilvēks tiek ievīts ikdienas norisēs un varās, un ḷauj aplūkot, kā primitīvas lietas, kā ādas krāsa un kustība, kḷūst par rīku, lai cilvēkus un ḳermeṇus pakḷautu "normalitātes” idejai.

Raksta mērḳis ir risināt, kā rase kḷūst par vienu no k̦ermeṇa pārvaldības prakses nosacījumiem, mainot gan to, ko nozīmē rase, gan to, kas par rasi tiek pārṇemts rasisma diskursos. Lai analizētu aspektus, kā rases ideja tiek pielāgota, tradēta un pakḷauta dažādām noteiksmēm un praksēm, rakstā tiek iepazīstināts ar franču domātāja Franca Fanona dekolonizēěanas analīzi. Rakstā tiek skatītas trīs prizmas: ḳermenis un rase, ḳermenis un ādas krāsas, k̦ermenis un ritms, lai norādītu, ka visas šīs pazīmes ir kopīgas daudziem k̦ermen̦iem un ka tomēr ir k̦ermeņi, kuri tiek normalizēti un slēpti no ikdienišşāa cilvēka redzesloka neatkarīgi no to etniskās un nacionālās piederības.

\section{Fanons un rase}

Francs Fanons (Frantz Fanon, 1925-1961) ir viens no 20. gadsimta domātājiem, kurš ir analizējis ne tikai rasisma izpausmes un biopolitikas varas formas, bet arī personīgo pieredzi, būdams francūzis, kurš kḷūst par vienu no alžīiešsiem (Macey, 2001, 17). Fanons savos darbos atklāj, ko nozīmē apzināties savu izcelsmi, savu ādas krāsu un to, cik liela nozīme ir viņa ķermeņa pārvaldībai un uztveršanai, atrodoties citā vidē. No vienas puses, viņš uzauga Martinikā, Francijas kolonijā, un, lai arī viṇam bija tumša ādas krāsa, pateicoties apkārtējai videi, viṇš sevi atpazina kā vienu no "baltajiem" cilvēkiem. No otras puses, atstājot Martiniku un cenšoties iestāties militārajos spēkos un vēlāk veltot savu dzīvi akadēmiskajai izglītībai un psihiatrijai, pētot melno cilvēku dzīves Francijā (Nayar, 2013, 17), Fanons piedzīvoja tik daudzas rasisma izpausmes, ka viṇš zināja - rasu diskriminācija ir jāaptur vai arī ir jāpalīdz tiem, kas cieš no rasisma visvairāk. Fanons pēc pāris gadiem devās rezidentūrā uz Alžīriju, kas l̦āva skaidrāk saprast, kas viṇš ir. Viṇš nevēlējās būt tas, kas apspiež citas sabiedrības grupas, diskriminē citu valstu iedzīvotājus, viṇš 
izlēma, ka viņš un viṇa ķermenis ir piederīgs alžīriešiem, viņš kḷuva par alžīieti, atdzīstot savu melnā cilvēka piederību. Pārdefinējot sevi, savu dzīves stilu un ķermeni, viṇš vērsās pret to, kas viṇam likās nepieṇemams - rasisms un rasu diskriminācija.

Francs Fanons analizēja alžīrieša (viņa tekstā - melnā) un kolonizatoru (viṇa tekstā - baltā) cilvēka un cilvēku grupas attiecības. Jā, Fanons izmantoja ādas krāsu kā grupu nošķirošu būtisku nosacījumu, taču ir vērts neaizmirst, ka rase, tāpat kā jebkurš cilvēku iedalījums, ir daudz plašāks un sarežğītāks. Rasi definē pēc cilvēka ādas krāsas, genētiskajiem parametriem, etniskās vai nacionālās piederības, ǵeogrāfiskās izcelsmes vai priekšteču saiknēm (Sankar, 2007). Pateicoties tam, ka jēdziens "rase” nav monosēmiska valodas vienība vai vienveidīgs novērojuma rezultāts, vēsturiski ideja par citu rasu cilvēku un grupu identificēšanu ir bijusi vienmēr klātesoša un ir iespējams analizēt rases izpausmes un raksturojumus arī pirms salīdzinoši jaunā "rases" jēdziena ieviešanas.

"Rase" raksturoja cilvēku grupas, kas nemācēja reǵiona valodu vai kas uzvedās un izskatîjās mežonīgi un barbariski (Zack, 2018; Alonso, 2017, 9)1', taču tāpat par rasi bija iespējams runāt kā par kategoriju, kas ir saistīta ar reliǵisku nostāju, elitāru uzvedību. Par rasi varētu runāt dažādos veidos un mēgeināt izsekot rases idejas dzimšanai vēsturiskajos avotos $^{2}$, taču neatkarīgi no rases dažādajām nozīmēm rase tiek skatīta kā cilvēku grupas atšḳiroša īpašība, runa ir par specifisku dotību, kas vieno un nosaka, vai cilvēki ir vai nav spējīgi iederēties (Fanon, 1963, 40). Fanona teorijā atsevišķka rasisma un rases analīze nebūtu bijusi pietiekama, tā ka būtiskāk bija pētīt pacienta traumas cēloṇus, t. i., rasisma atstātās ideoloǵijas nospiedumus cilvēku k̦ermenī, psihē un izpratnē.

Protams, ir iespējams izcelt īpašības, kas tiek izmantotas rases koncepta izveidei, piemēram, ādas krāsa, galvaskausa lielums, acu krāsa, matu struktūra, galvaskausa forma, stāja un augums līdz ar inteliǵenci un sabiedriskumu u. tml., tomēr rasi nosakošie pamatelementi (tie, kas ieformē rases nozīmes) ir cieši saistīti ar politiskajām, sabiedriskajām, kulturālajām izpratnēm. Pamatelementu (vai tā būtu ādas krāsa vai izcelsme, vai etniskā piederība u. c.) izvēli nosaka sabiedrības prakses un funkcijas, kopējie mērḳi un uzdevumi, atklājot, kā koncepts kā rase un tā

\footnotetext{
${ }^{1}$ Naturālajā antropologiijā vēl joprojām tiek izmantots nojēgums par rasēm, lai ar novērotām fiziskām un uzvedības īpašībām atšḳirtu dažādas rasu/cilvēku grupas. Mēǵinājums bija pamatot rases ideju ar bioloğiskiem un ievācamiem datiem, piemēram, galvaskausu izmēri, dzīvesveids, izskats tika uzskatīti par katrai grupai atšķirīgu īpašību.

2 Sk., piemēram, Brunner, Otto; Conze, Werner; Koselleck, Reinhart (Hrsg.) (1994). Geschichtliche Grundbegriffe: historisches Lexikon zur politisch-sozialen Sprache in Deutschland. Band 5: Pro-Soz. Stuttgart: Ernst Klett, pp. 166-177.
} 
apzināšanās veicina sevis un svešinieku kā Citu nošķiršanu (Mbembe, 2019, 132). Arī Fanonam nozīmīgākas bija attiecības rasisma ideoloǵijas īstenošanā nekā tas, kas cilvēkiem tika piedēvēts kā rases grupai vienlīdzīgs un vienādi piederīgs, svarīgi bija pareizā/nepareizā, savējo/svešo, mans/cits nošķīrumi.

Cits ir pretstats sev pazīstamajam un nepieciešamība, lai praktizētu idejas par savu pārākumu, normalitāti un pien̦emamo un piederīgo (Miles, Brown, 2003, 52). Rezultātā rase nav nepieciešami negatīvs apzīmējums, tas palīdz saprast apkārtesošo vidi un rast atbildi, kas ir tas, kas cilvēku padara atškkirīgu un īpašu, taču rases identificēšana l̦oti ātri var kḷūt par varas rīku. Fanons, piemēram, ir norādījis, ka rase kḷuva par nosacījumu kolonizēšanas procesā, kur vadošā rase ir tā, kas ir ieradusies no citurienes, tie, kas ir atšķirīgi no pamatiedzīvotājiem, tie, kurus var definēt kā "tie citi" (Fanon, 1963, 40). Līdz ar to sākotnēji, attīstoties rasismam, kolonizēšanas procesos runa bija ne tik daudz par vardarbību, ko kolonizētie afrikāṇi izjuta, cik par nesapratni, kas radās, kad alžīriešiem tika teikts, ka viṇi ir jāizglīto un jāpārmāca atbilstoši kolonizatoru pārliecībām (Fanon, 1986, 89). Kolonizatori ieradās ar pārliecību, ka pastāv primitīva rase, kas ir tuvāka dzīvnieciskajam, un attīstītāka rase, kas ir spējīga uz izaugsmi un sabiedriskumu. Kolonizatori pamatoja savus spriedumus "zinātniskajā rasismā”, cilvēkus raksturojot pēc novērojamajām īpašībām (ādas krāsas, matu struktūras, izskata, dzīves stila, potenciālās galvaskausa formas), kamēr alžīiiešiem rase pastāvēja vien kā parametrs, lai atšķirtu sevi no jauniebraucējiem. Taču rase un manāmā iedzīves, ǵeogrāfiskā un fiziskā atškirīība bija viens no rīkiem citas cilvēku grupas atšḳiršanai un kontrolei. Runa ir par vardarbīgu k̦ermen̦a idealizēšanu un pakḷaušanu jauniem standartiem, runa ir par rasismu, ko var piedzīvot kā dažādu ādas krāsu cilvēki, tā arī vienas sabiedrības grupas piederīgie, diskriminējot citus līdzdzīvotājus etniskās, nacionālās, ādas krāsas u. c. piederības dēḷ. ${ }^{3}$

Rasisms ir ideoloǵija, ideju un uzskatu kopums, kas ietekmē ne tikai valodu, attieksmes, bet arī uzvedību un varas un pārvaldes prakses un stratēgijas, kas pamatojas idejā, ka rases ir nevienlīdzīgas, t. i., ir pārākas un zemākas cilvēku grupas. Nošķirot citas rases, izceḷot dažus kā pārākus, tiek veicināta k̦ermen,u objektivizēšana, ķermenis tiek skatīts nesaistîti ar emocijām, kā maināms, formējams objekts un nevis kā piederīgais

\footnotetext{
${ }^{3}$ Latvijā rasisms izpaužas, piemēram, kā etnisko grupu (mazākumtautību) diskriminēšana un svešvalodas (piemēram, krievu valodas) nepieņemšana un nicināšana, citas formas varētu būt ieceḷotāju un imigrantu neatzīšana un/vai pārlieka intereses pievēršana. Rasisms, jāpatur prātā, nav tikai citu ādas krāsu diskriminēšana, bet gan citu cilvēku (nepamatota) diskriminēšana viṇu etniskās, nacionālās, ǵeogrāfiskās piederības un tikai sekundāri fizisko īpašību dēḷ.
} 
savai grupai. Drīz vien rase jeb drīzāk rasisms kḷūst par ikdienišḳu biopolitiskās vara praksi, kas nosaka, kā katram k̦ermenim ir jādzīvo un jāmirst, ietekmējot k̦ermeṇa izskatu, pārliecības, ritmu un būšanu. Zinātnes diskursā rase un rasisms kḷūst par daḷu no zinātniskā rasisma, mēǵinājumiem pierādīt, ka pastāv empīriski dati, ka rase ir ǵenētiska un ka rasu pārākums, diskriminācija un neattīstība ir patiesi nosacījumi. Taču, attīstoties metodoloǵijām un tehnoloǵiskajām iespējām, drīz vien tiek secināts, ka rase kā grupa ar vienotām īpašībām nav pilnībā pamatojama ǵnenētiska parādība (Zack, 1998, 3-4). Rase drīzāk ir skatāma kā izcelsmes parametrs, bet ne nosacījums, kas noteiktu piederību un pārākumu.

Rezultātā rasisms ietekmē gan uzskatu, ka rases var būt nelīdzvērtīgas ǵeogrāfisko un bioloǵisko faktoru dēḷ, gan kulturālo, etnisko jeb nacionālo un simbolisko rases konceptu (Šuvajevs, 2019, 159-160). Rasisms nav tikai bioloǵisku īpašību piedēvēšana un raksturošana, rasisms kḷūst par rīcību, valodas un uzvedības daḷu. Rasisms ir visu iesaistīto pušu pārṇemšana ciešās attiecībās, no kurām rasisma diskusijā iesaistītie nespēj vairs izkḷūt (Braude, 2011, 42), jo viṇi atrodas apburtajā lokā, vien otru nepatraukti formējot kā Citu vai sev piederīgo. Rasisms izpaužas savā ziṇā “vulgāri”, izvērtējot, kurai cilvēku grupai ir piemērotāks galvaskauss sociālai dzīvošanai, tomēr rasisms visbiežāk izpaužas neapzināti caur savu kultūru un savām ikdienas praksēm, noliedzot vai uzskatot par nepietiekamu noteiktas grupas dzīves stilu un veidu (Mbembe, 2019, 130). Rasisms un pat rases jēdziens nav tikai attieksmes jautājums, tas ir jautājums par to, ko šie jēdzieni simbolizē.

\section{Atbilstoši krāsains}

Rasisms un rases koncepts pakḷauj sociālo, politisko, ekonomisko un citas ikdienas sfēras (Šuvajevs, 2019, 159-160) pārmaiṇām un jaunām attiecību veidošanās mehānikām. Rase nav tikai svarīga, ja citas cilvēku grupas sastopas, rase veido to, ko katrs saprot ar sevi un savu piederību. Pat ja visi grupā dzīvojošie ir "piederīgi vienai rasei”, viṇu ǵenētiskās piederības, izskata īpašības var būt atšķirīgas un nenoteiktas: pat diviem eiropiešiem varētu būt mazāk līdzību vienam ar otru nekā ar kādu iecel̦otāju. Taču vai bioloǵiskā līdzība ir tā, kas nosaka, kā cilvēks uztvers svešiniekus un sevi?

Fanons ticēja, ka kolonizatori bija tie, kuri pakḷāva alžīriešu ķermeņus un tos ievijuši mìtos un stereotipos par un ap primitīvismu (Nayar, 2013, 113), t. i., alžīrieši tika skatīti kā iracionāli un neattīstījušies vai noteiktās situācijās saistīti ar īpašībām: slepkavniecisks, mežonīgs, nepaklausīgs (Nayar, 2013, 54). Taču, lai arī Fanonam melnais ķermenis ir svarīgs un visbiežāk baltais ķermenis tika kritizēts, varas praksē tiek 
iesaistīti visi - arī baltais ķermenis tika ietekmēts ar iemācītajām idejām un uzdevumiem, dodoties kolonizēt teritoriju, spīdzināt citādos u. tml. Līdz ar to, iespējams, tas, ko raksturo Fanons, ir izsakāms citādi - citi var ietekmēt manu ķermeni tikpat l̦oti, cik es - citu k̦ermeni neatkarīgi no izskata un dzīves stila. Runa ir par divu k̦ermeņu sastapšanos, viena otra sastapšanu Es-Citi attiecībās, iepazīstoties un cenšoties tvert vienam otru savā valodā, ritmā un dzīves izpratnē.

Ķermeña pārvaldības (biopolitikas) vara ielenc katru, nosakot, kā katram cilvēkam dzimt, dzīvot un mirt, un tiek ietekmēti kā k̦ermeṇi, tā kultūra un izpratne par pareizo un nepareizo. Tiek kontrolēta ne tikai dzīvotspēja, bet arī izskats, kas, par spīti bioloğiskajiem parametriem, kultūrā var būt uzskatīts par kaut ko izmaināmu. 1975. gadā filosofs Mišels Fuko (Michel Foucault, 1926-1984) darbā "Uzraudzīt un sodīt”" (Surveille et Punir) ir rakstījis: "ḳermenis ir tieši iegremdējies politiskā laukā; varas attiecības to tūlìt sagrābj, tās ielenc to, iezīmē, dresē, moka, piespiež strādāt, uzliek tam par pienākumu ceremonijas un prasa no tā zīmes." (Fuko, 2001, 28) Ḳermenis ir neizbēgami noteikts, tā nozīmes un jēgas ir pakḷautas apkārt notiekošajam tik l̦oti, ka, iespējams, es un mans k̦ermenis ir domājams nevis nošķirti, bet mijiedarbībā ar noteiktām normām, krāsām, citiem, rīcību un idejām. Cilvēks un tā ḳermenis ir cieši saistīts ar jebkuru no varas praksēm, pat ja ādas krāsai nav nozīmes, citā vidē krāsa var būt nosakošs faktors, kas kḹūst par nepieciešamību, iepazīstot jaunus ķermeņus, kas ne tika izskatās citādi, bet arī dzīvo un funkcionē atškirīgāk.

Iepazišanas procesā ḳermenis tiek pakḷauts tai varai, kas, tverot apkārt notiekošo, grib redzēt, zināt un atpazīt sākotnēji nezināmo (Kaneti, 1999, 9). Iepazītais cits, kurš uzvedas neierasti, izskatās sveši un dzīvo citā vidē, noteikti biedē. Nezināmā aptveršana ar sev zināmiem parametriem ḷauj izvairīties no bailēm, kas cilvēkus vieno un ḷauj uzturēt ciešas savstarpējās attiecības (Kaneti, 1999, 10). Rezultātā vēsturiski svešā cilvēka uzvedība tiek korelēta ar viṇa sociālo stāvokli, izglītības līmeni un - triviālāk - ar dzimti vai pat rasi. Šḳietami cilvēks baidās no tā, kā svešais uzvedīsies, izskatīsies un vai cilvēks būs primitīvs kā dzīvnieks mežonis, tomēr biedējošais ir nevis svešã cilvēka primitīvisms, bet gan nespēja atpazīt un kontrolēt Cita k̦ermeni. Varbūt biopolitiskās prakses nav apzinātas, taču cilvēkiem ir svarīgi spēt kontrolēt jeb ieformēt citus cilvēkus atbilstoši savām normām un pieredzēm - varas ielenktībā tiek ierauts gan jauniepazītais, gan uztvēēēja ķermenis, lai būtu iespējams turpināt ikdienas norises bez pārtraukumiem.

Kultūra tās dialektiskajā (es un citi, indivīds un sabiedrība) formā ir ne tikai ķermeņu aptveroša, bet arī formatīva - kultūra, lai spētu sevi uzturēt, ķermeni veido kā kaut ko nozīmīgu (Nürnberger, 2015, 46-47). 
Kultūras nozīmes ir tikpat daudzveidīgas, cik katra cilvēka ķermenis, kas cauri laikam vienmēr tiek pakḷauts kādam skaistuma, labuma, ērtības ideālam. Viens no cilvēku grupēšanas nosacījumiem ir rase, kas palīdz atšḳirt, identificēt un informēt citus un sevi par savu piederību kādai grupai un noniecināt citus, kas pieder kādai it kā zemākai rasei. Taču tā vara, kas pārṇem ķermeṇus vēsturisko ideju dažādību un rasu iespaidā, atklāj, ka ne viss k̦ermenis ir kontrolējams. Vara skar tikai vienu no sociālā k̦ermeña aspektiem (Foucault, 2003, 70), otru k̦ermeņa pusi (atstumtos un nepieņemamos, citādos un svešos) atstājot ēnā. Ēnā tiek atstāts neiederīgais un standartam neatbilstošais.

Fanons savos darbos rakstīja par to, kā kolonizēšanas un dekolonizēšanas procesos melnais cilvēks pārdzīvoja un piedzīvoja sava ķermeņa normalizēěanu (procesu, kurā tiek noteikta cilvēka identitāte un rīcība pretstatā citiem), pārveidošanu (ḳermeṇa un dzìves formas mainišanu) un tīrǐšanu (ādas krāsas mazgāšanu). Ādas krāsai nebija nozīmes, runa bija par to, ko vara spēja pārn̦emt sociālā k̦ermen̦a veidošanā, t. i., nozīmes un simbolus, ādas krāsa bija vien nozīmju lauks, kas tika izmantots, atstājot cilvēka bioloğisko būšanu kā nesvarīgu (ēnas pusē). Tiklīdz cilvēkam tiek atṇemta kāda dạ̦a, ko viņš vairs nekontrolē, cilvēks vairs nav spējīgs sevi atpazīt vai arī atrodas starp ḳermeṇu pārvaldību un savu varas noteikšanu.

Fanons izjautāja savu un savu pacientu sevis uztveršanu, taču līdz ar viṇu 20. gadsimta pirmajā pusē vairāki domātāji pievērsās negritīdu kustībai (Diagne, 2018) - mēgeinājumam atgūt vārda Négrité nozīmi, ko sākotnēji izmantoja, lai izsmietu un zākātu melnos cilvēkus. Jaunajai nozīmei bija jānorāda, ka tie, kas identificējas kā melnie cilvēki, spēj sevi paši definēt un raksturot kā vērtīgus, svarīgus un norādīt, ka būt melnam nav kaut kas slikts, tieši pretēji - tā ir sava ķermen,a, balss atgūšana, savas varas pārṇemšana. Tomēr savas varas atgūšana, ja cilvēks tiek ierauts jaunās nozīmēs, ir sarežğīta.

Fanons pauda savu vilšanos par to, kā Alžīrijas līdzcilvēki kolonizēšanas un dekolonizēšanas procesos ir cietuši kolonizatoru ideālu un "baltā skatiena” dēl (Fanon, 1986, 110). Fanona un viṇa līdzcilvēku ķermeṇi tika iegremdēti aizspriedumos un raksturoti kā negatīvi ${ }^{4}$, tos pretstatot kolonizatoru k̦ermen̦iem un izpratnēm par pareizu k̦ermeni. Jaunais ideāls, ar ko cilvēki sastapās, vilināja viṇus mainīt savu valodu, savu kultūru un pat savu ādas krāsu. Balto skatienu ietekmētie tumšādainie cilvēki izjuta nepieciešamību mainīt ne tikai savu mentalitāti (iekšējo k̦ermeni), bet arī ārējo ķermeni - ārējo izskatu un dzīvošanas stilu. Fanons raksta,

${ }^{4}$ Īpatnēji, bet vārds "negatīvs” žargonā burtiski nozīmējot "nēgeeris”. Sk.: Kavalieris, Anrijs (sast.). (2002) Tā runā zonā. Latvijas argo - kriminālvides žargona vārdnīca. Rīga: Valters un Rapa, 75. lpp. 
ka cilvēki ir jutuši nepieciešamību pēc "atnēgerošanas" (denegrification) jeb sava ķermeņa balināšanas (Fanon, 1986, 110), lai spētu iederēties jaunajā ḳermeṇa ideālā. Melnais cilvēks sajuta nepieciešamību "kḷūt par cilvēku starp cilvēkiem” (Fanon, 1986, 112). Iederēšanās citu sabiedrībā prasīja sava k̦ermeņa maiņu, un k̦ermenis kḷuva nevis par kaut ko dotu, bet par objektu, kuru ir iespējams mainīt - gan citiem, gan pašam.

Fanona pasaules skatījumā ne tikai melnais ķ̧ermenis iemācās sevi uztvert kā nepiemērotu, bet arī baltais ķermenis iemācās uzvesties noteiktā veidā. Ķermen̦i ir tik cieši savīti ar ideāliem, ka tie kḹust ieslodzīti (Nayar, 2020, 217) un savu k̦ermen,a nozīmi atzīst tikai caur nebrīvi jeb normām, kas tiek iemācītas. Taču kā nebrīvie, tā brīvie drīz vien praktizē ķermeni ikdienas ritmā, par kopīgu dzīvošanas veidu attaisnojot, definējot rīcību, kas veidoja un veido ķermeni un ikdienu (Fanon, 1963, 223). Skatît savu ķermeña ārējo izskatu kā nepieņemamu kḷūst par ikdienišķu rīcību, jo vide, kurā cilvēks uzturas un domā, ir cieši saistīta ar k̦ermeñiem un telpu, kas tos ielenc (Bourdieu, 2013, 89). Visas pieredzes (mīti, valodas iestrādnes, rīcība) manipulē un veido k̦ermeni un to, kā cilvēks sevi pieredzēs. Melnais ḳermenis iemācās sevi ierobežot, kamēr baltais ķermenis iemācās rīkoties, kā to ir mācījuši viṇam apkārt esošie. Tomēr nav noliedzams, ka konflikts var pastāvēt starp dažādiem baltiem kiermen̦iem un starp dažādiem melniem k̦ermen̦iem, ne velti Fanons kḷūst par alžīrieti, nevis tāds sākotnēji ir, un ne velti vēsturiski arī balts ķermenis ir izjutis neiederību savā vidē.

Krāsainie ḳermeṇi, pat ja līdz̄̄gi, tomēr līdzdala traumatisku pieredzējumu jeb bailes, ka es vai kāds cits kḷūs par kaut ko svešu un nesaprotamu. K̦ermeṇi cenšas pielāgoties apkārtesošajiem norādījumiem un varas ietekmēm, kā nekā "[ī]stenībā vara rada; tā rada reālo; tā rada objektu sfēras un patiesības rituālus. Indivīds un zināšanas, ko var no tā paņemt, nāk no šīs radǐšanas” (Fuko, 2001, 177). Bet kas tiek radīts? Tiek radīts ritms, jauna ikdiena, jaunas k̦ermeṇu kustības - atbilstīgi k,ermeñi. Melnais kermenis, vēlēdamies līdzināties baltajam ḳermenim, maina savu stāju, savas kustības, savu runas mākslu, baltais ḳermenis savā ritmā iekḷauj iepazīto un pakḷauj citus savam ikdienas ritmam. Protams, ir ķermen̦i, kas pretojas un turpina savu ritmiskumu, dzīvojot straujākā, vardarbīgākā taktsmērā, sekojot straujākiem soḷiem un mītiem.

\section{Ritmiskais k̦ermenis}

Ja kāds cits ieraudzīs kādu mežonīgi dejojot, ḷaujoties visām konvulsīvajām iecerēm, tad, iespējams, centīsies šo k kermeni sasaistīt ar novēroto uzvedību. Sabiedrisks cilvēks taču neḷausies tām un nedejos haotiski. Sabiedriskam cilvēkam ir ritma izjūta, soḷu skaits, treniṇš un disciplīna, 
sabiedriskais k̦ermenis jau ir ieformēts un varas pārņemts. Tomēr - vai mežonīgā dejošana, sekošana izjūtām ir raksturīga tikai nesabiedriskam, nedomājošam un neapvarotam (varas nepānnemtam) k̦ermenim?

Ḳermeni un kultūru vieno nepieciešamība pēc ikdienišk̦as sevis praktizēšanas. Ḳermenim ir jāiemācās noteiktas tehnikas, lai būtu iespēja īstenot noteiktu ieradumu (Mauss, 1973, 71-72). Varētu teikt, ka ḳermenis nav pilnveidojies, līdz tas nav iemācīts rīkoties saskaņā ar noteikumiem. Un ideja par noteikumiem, normālu izskatu kḷūst svarīga, tiklīdz tiek sastapts kāds nepaklausīgs, nepazīstams k̦ermenis. Ķermeṇa ārējais izskats, tāpat kā performance (izmantotās skaņas un zīmes), l̦auj nodrošināt cilvēku sanākšanu, satuvošanos un publiskās sfēras aptveršanu (Butler, 2015, 20). Taču nevis valoda vai kustības pašas par sevi nosaka, kad un kā cits cilvēks tiks uzskatīts par svešu un nepazīstamu radību, nozīme ir ritmam jeb neapzināti un apzināti praktizētajām un veidotajām izpratnes saitēm (Marriott, 2018, 92). Konvulsīva kustība ir neparedzama, kamēr saprātīgajam un inteliǵentajam k̦ermenim pat konvulsīva rīcība ir apdomāta un pakḷauta jau esošiem k̦ermeṇu rāmjiem un darbību formulām.

Melnais k̦ermenis tika uzskatīts par “emociju čempionu”, kamēr baltais tika skatīts kā inteliğentākais un dzeltenais kā darbīgākais (Macey, 2001, 185). Katram k̦ermenim piemīt kāda ritmiska iezīme. Cilvēki, kas vēlas būt kaut kas vairāk, nekā viṇi ir, paḷaujas uz kāju ritmu - līdzinoties zvēru bariem, "viṇu soḷi neapklust, tie atkārtojas un ilgu laiku saglabājas vienādi skaḷi un dzīvīgi” (Kaneti, 1999, 24). Tomēr ne tikai soḷu ritms ir noteicošs, ķermeņiem noteicoša ir kustība kā izpausme. Lai arī ritmisks ķermenis ir praktizējošs ķermenis, t. i., tas kustas, lai kaut ko sasniegtu un panāktu, viens no ritmiskā ḳermeṇa paveidiem ir izlādēšanās un sevis dziedēšana. Fanons, raksturojot alžĩriešus, runā par cilvēkiem, kuri pēc soda izjušanas, pātagu sitieniem, mēgeinot sasniegt atslābumu, vienojas muskuḷu orǵijā jeb deju apḷos, kas palīdz izlādēties un atbrīvot ķermeni no sakrātās vardarbības (Fanon, 1963, 57).

Emocionalitāte, kustīgums un kopība ir dal̦a no ritma, kas raksturo alžīriešus, kādus tos pazīst Fanons, taču citiem Āfrikā sastopamā deju kultūra liek izjust piesardzību, jo viṇu ikdienas ritms atšķiras. Kamēr alžīrieši un koloniālās pasaules pārṇemtie dejo ekstātiski, līdz nogurdina savus locekḷus un atslābina emocionālo piesātinājumu, tikmēr cits šo deju izprot kā vājību, jo alžīrieša emocijas ir redzamas, pat histēriskas un atklātas kā to k̦ermen̦i (Fanon, 1963, 56-57). Fanons raksturo situāciju, kurā baltā sieviete ar motoriem traucējumiem cenšas pārvarēt savu stāvokli ar terapiju. Terapijas laikā sieviete, iedomājoties dejojošus cilvēkus, galvenokārt tos iztēlojās kā melnos cilvēkus, kas patvalı̄igi dejo ap ugunskuru un apdraud citu cilvēku k̦ermen̦us. Taču Fanonu fascinē šĩ situācija, jo izrādās, ka sieviete ir uzaugusi vidē, kur viṇas bailes no afrikāṇu 
mūzikas, cilvēkiem tiek izmantotas, lai viṇu ietekmētu kāda mērḳa sasniegšanai (Fanon, 1986, 206-209). Runa nav tik l̦oti par melnā/baltā ķermeña attiecībām, cik par konstitucionāliem mītiem, ikdienas valodu, citu cilvēku rīcību, kas īsteno sekas - bailes un motoros traucējumus jaunajai sievietei.

Bailes un neapzinātos mītus ir iespējams īstenot ne tikai dejas un dejojošo kontekstā, bet arī citos ķermeni pārvaldošos jeb nosodošos procesos. Fanons raksturo situācijas, kurās alžīriešiem tika mācīts uzvesties atbilstoši kolonizatoru dzīves ritmam. Alžīrietim bija jāatsakās no savas iekšējās dzīves - mītiem, ticībām un māṇticībām, lai apvienotu subjektīvo un dzīvojamo dzīvi (Gordon, 2015, 48). Taču kolonizatori ietekmēja ne tikai alžīriešu dzīves ritmu, bet arī valodas un nozīmju struktūras. Kolonizatoru izmantotā valoda saziṇā ar alžīiriešiem liecināja, ka alžīrieši tiek uzskatīti par slimiem un veǵetatīvā stāvoklī esošiem, vēl jo vairāk - par dzīvnieciskiem (Fanon, 1963, 43). Savukārt ir saprotams - ja cilvēkam apkārt visi tērpjas noteiktā veidā, tad citādais geērbšanās jeb neǵērbšanās stils liek vēlēties izprast, kas notiek citu prātos. Rezultātā cits dzīves stils, citādāka deju kultūra, ḳermeṇa rotāšanas tradīcija, kustības tika skatītas kā kaut kas mežonīgs, kas palicis cilvēkam no tā primitīvā prāta (Ehrenreich, 2006, 7). Un mežonība nav ritmiska, tā šķietami nepazīst, ko nozīmē iederēties, zināt un būt nosvērtam.

Divu k̦ermeņu rasistiska sastapšanās ir ne tikai cita nodēvēšana par mežoni, bet arī savu vērtību, vēstures un dzimtenes piesaukšana, otru it kā pārliecinot, ka visiem būtu jāseko viṇa piemēram (Fanon, 1963, 51). Vēsture, kas tiek citiem iemācīta, nav neitrāla, tā drīzāk ir ideju un savu vērtību vēsturiskums, taču, visticamāk, šī vēsture, kas tiek pārliecināti mācīta iepazītajiem cilvēkiem, ir tikai tās varas atbalsis, kurā šis cilvēks ir dzīvojis. Esot melnam vai baltam, vai citādi krāsotam, ir jāpatur prātā, ka runa ir par sociāli simbolisku (socio-symbolic) būšanu (Žižek, 2009, 62). Ķermenis tiek paḳ̣auts, pienemts vai izstumts nevis izskata dēḷ, bet nozīmju dẹl, kas k̦ermenim tiek piedēvētas. Tāpēc arī Fanona analizētajās situācijās alžīrietis, kuru uzskata par mežonīgu, tiek uzskatīts par mežoni gan izskata, gan uzvedības, gan valodas dēḷ.

Kustība ir cieši saistîta ar k̦ermeņa formu, izskatu un kā iekšējās, tā ārējās būšanas veidiem. Katrai sabiedrībai un grupai ir savi ieradumi un tehnikas, kā noteikt katru procesu (Mauss, 1973, 71-72). Ja cilvēks ir uzaudzis vidē, kur viṇš var brīvi kustēties virzienos, kuros vēlas, cilvēks, kas ir uzaudzis sistemātiski būvētā "sabiedriskā" vidē, seko kustībām un nosacītajai brīvībai. Līdz ar to tad, kad ierodas kolonizators, kas tagad pārmācīs, iemācīs un izmācīs melnos ķermeñus rīkoties pienācīgi - atbilstoši pieņemtajām normām, ideāliem, runa ir par svešā, nepazīstamā ķermen̦a pielīdzināšanu savam (kolonizatoru) k̦ermenim, iepazīstinot to 
ar savu izpratni. Ādas krāsa kḷūst par būtisku faktoru ideoloǵijas seku dēḷ, nevis nepieciešamības dēḷ, jo pat dažādu vecumgrupu, dažādu reǵionu (ne nepieciešami rasu grupu) cilvēki var būt ar atšķirīgiem ikdienas paradumiem, uzvedumiem un praksēm.

\section{Noslēgums. Jaunais kermenis}

Pašnoteikšanās un sava vara pār ķermeni un dzīvi un dzīvību ir vardarbīgs process, cilvēks nekad nav paša noteikts, un sarežǵītāk ir formēt ķermeni, kad cilvēkam tiek mācīts, kā pareizi locīties, grozīties un kustēties, izskatīties un runāt. Šḳietami skološana un ikdienas pārveidošana nav nepieciešami sāpīgs process, taču ieradumu un jauno varu nosacījumi atrodas pastāvīgā diskusijā. Jo ilgāk cilvēks trenējas, jo vienmērīgāku dzīves stilu ievēro - k̦ermenis pierod un spēj darboties tāpat kā apkārtesošie cilvēki. Taču, ja k̦ermeṇa funkcijas tiek vardarbīgi ietekmētas, cilvēks iemācās (ḳermenis atceras) izjusto varu un pats kḷūst par daḷu no vardarbīgās varas. Rasisma gadījumā mocītais ḳermenis iemācās rīkoties kā mocītājs.

Fanons, piemēram, raksturo situāciju, kā vardarbības rezultātā alžīrietis kḷūst par kolonizatoru. Alžīrietis nevis pārṇem kolonizatora īpašības, kādas tās izpaužas, dzīvojot starp savējiem un nekolonizējošā situācijā, bet tās īpašības, kuras alžĩrietis ir iepazinis kolonizācijas procesā - kolonizatora agresiju un stājas veidu, runas stilu un cēlumu vai lepnumu. Alžīrietis apzinās, ka viņš ir tikpat l̦oti cilvēks, cik kolonizators (Fanon, 1963, 45), bet tēls, ko vin̦š ir iepazinis, ir rīkojies netaisnīgi un vienmēer centies apspiest citādo un uzspiest savu pārliecību. Rezultātā, sastopoties vairākiem ideāliem un izpratnēm par ideālo cilvēku (t. i., alžīrietim ieraugot kolonizatora varu), ideju ietvari, kurus pazīst dažādie ķermen̦i, sastopot viens otru, piedzīvo pārmaiņu un pretrunu piesātinātu procesu. Veids, kā atrisināt pretrunas un atbrīvot savu ķermeni, ir trenēties (Mauss, 1973, 77) jeb veicināt jaunus ieradumus, kas Fanona un alžĩriešu gadījumā izvērtās par rīcību "aci pret aci”.

Alžīrietis mācās no kolonizatora un pārṇem viṇa vardarbīgo pārvaldību, kas īstenojās alžīriešu pātagošanā, izvarošanā, sišanā un mocīšanā, ķermeṇu kaunināšanā un apvārdošanā (Fanon, 1963, 52). Alžīrietis diemžēl mācījās nevis no kolonizatora, kurš atradās savā vidē, bet no kolonizatora, kas pats kḷuva par mežoni jaunajā citu cilvēku piederīgajā vidē, līdz alžīrietis kḷuva par mežoni, par kādu tas tika uzskatīts. Jaunais ķermenis bija vēl vardarbīgāks un skarbāks, jo, aț̣emot brīvību pašam noteikt sava ḳermen,a nozīmes, uzspiežot noteiktas vērtības izskatam un izcelsmei (Oliver, 2003, 191), cilvēks jauno identitāti var formēt tikai ar tiem jēdzieniem, kurus viṇš ikdienā dzird un lieto. 
Cilvēks kḷūst par cilvēku pasaulē ne dzimšanas, ne senču, izcelsmes un rases dēḷ, bet gan pateicoties vēlmei pilnveidoties: ceḷot, pārvietoties (kustēties) un main̄ities (Mbembe, 2016, 187). Kā Fanona stāstā alžīrietis tiek pakḷauts dažādiem ideāliem - krāsa, dzīvesveids, kustību visaț̣autība, tā arī ikdienā cilvēks un tā kịermenis ir saistīti ar daudz sarežğîtākiem konceptiem, kas varbūt ierobežo, bet varbūt atbrīvo paša būšanu. Iespējams, rase ir nevis koncepts, kas tiek izmantots varas uzturēšanai un dzīvojošo un mirstošo kontrolei, bet gan kḹust par diskursu, veidu, kā ietekmēt un pozicionēt citus cilvēkus. No vienas puses, rase (un rasisms - cilvēku rasiskošana) l̦auj nošḳirt sevi no citiem, veidot attiecības, kuras pamato bioloǵiski (ticot, ka ir pārākas rases), no otras puses, runa ir par normalizēšanu: veselīgas, tīras sabiedrības veidošanu (Fanon, 2003, 255-256) - rase kḷūst par nosacījumu drošības, politiskās vienlīdzības, sociālo struktūru veidošanai.

Rase, dzimums, etniskā piederība, seksualitāte ir šḳietami vieni no fiziskajiem parametriem, kas cilvēkus ḷauj ievietot kādā izpratnes rāmī (eiropeīds/ekvatoriāls, melns/balts, sieviete/vīrietis, vietējais/ieceḷotājs), kas ḷauj cilvēkam izlemt, kā sevi definēt limitētā valodas un prakšu rāmī. Taču šie parametri vēl jo vairāk tikai palīdz izdzīvot un dzīvoties līdz ar noteiktiem konceptiem: pien̦emams/nepien,emams, drošs/nedrošs, savējais/svešais. Esot ārkārtējam - svešam vai citādam, esošais prakšu lauks vai nu pakḷaujas izmaiṇām, ieviešot jaunas darbību kopas, vai arī citus cilvēkus izslēdz un uzskata par nenormāliem. Tomēr šĩ ārkārtējība un savas identitātes pakḷaušana jaunajiem diskursiem ir mēǵinājums atkal atklāt savu k̦ermeni - vēlme pārveidoties, lai spētu izlauzties no uzspiestās normalitātes. Izlaušanās un sava apspiedēja pārvarēšana īstenojas ne tik daudz sevis atgūšanā, cik jauna ķermeṇa izveidošanā, un sava pirmstāvokḷa atgūšana ir neiespējama, ja arī tālākajā dzīves procesā cilvēks tiek apspiests, ieformēts, kontrolēts un nozīmju pārņemts. Tomēr Fanona raksturotā situācija ir ne tikai alžīrieša stāsts, bet komplicēta vairāku ķermen̦u pieredze, kas kḷusst par daḷu no valodas, vēstures, ķermeñiem un praksēm. Nav jābūt alžīirietiem vai Fanonam, lai apzinātos, ka identitātes un rases attiecības nav tikai melnbaltas, drīzāk katrā reğionā ir iespējams runāt par dažādu rasu interpretācijām un rasisma formām.

\section{Bibliogrāfija}

Alonso, Juan Luis García. (2017) Whoever is not Greek is Barbarian // Arnaut, Ana Paula. (Org.) Identity(ies). A Multicultural and Multidisciplinary approach. Coimbra: Coimbra University Press, pp. 9-26.

Bourdieu, Pierre. (2013) Outline of a Theory of Practice. Cambridge: Cambridge University Press. 
Braude, Benjamin. (2011) How racism arose in Europe and why it did not in the Near East // Racism in the modern world. Historical perspectives on cultural transfer and adaptation. New York: Berghahn Books.

Butler, Judith. (2015) Notes Toward a Performative Theory of Assembly. Cambridge: Harvard University Press.

Diagne, Souleymane Bachir. (2018) Négritude. Pieejams: https://plato.stanford.edu/ entries/negritude/

Ehrenreich, Barbara. (2006) Dancing in the Streets. A History of Collective Joy. New York: Metropolitan Books.

Fanon, Frantz. (1963) The Wretched of the Earth. Transl. C. Farrington. New York: Grove Press.

Fanon, Frantz. (1986 (1967)) Black Skin, White Mask. Transl. Ch. L. Markmann. London: Pluto Press.

Foucault, Michel. (2003) Society Must Be Defended. Lectures at the Collège de France, 1975-76. Transl. D. Macey. New York: Picador.

Fuko, Mišels. (2001) Uzraudzīt un sodīt. Cietuma rašanās. Rīga: Omnia mea.

Gordon, Lewis R. (2015) What Fanon Said. A Philosophical Introduction to His Life and Thought. New York: Fordham University Press.

Kaneti, Eliass. (1999) Masa un vara. Tulk. I. Šuvajevs. Rīga: Jumava.

Lévi-Strauss, Claude. (1952) Race and History. Paris: UNESCO.

Macey, David. (2001) Frantz Fanon. A Biography. New York: Picador.

Menakem, Resmaa. (2017) My Grandmother`s Hands: Racialized Trauma and Pathway to Mending Our Hearts and Bodies. Las Vegas: Central Recovery Press.

Marriott, David. (2018) Whither Fanon? Studies in the Blackness of Being. Stanford: Stanford University Press.

Mauss, Marcel. (1973) Techniques of the Body // Economy and Society, 2(1), pp. 70-88.

Mbembe, Achille. (2019) Necropolitics. Transl. S. Corcoran. Durham: Duke University Press.

Miles, Robert; Brown, Malcolm. (2003) Racism. Second Edition. London: Routledge.

Nayar, Pramod K. (2013) Frantz Fanon. London: Routledge.

Nayar, Pramod K. (2020) Fanon and Biopolitics // Byrd, Dustin J.; Miri, Seyed Javad. (Eds.) Frantz Fanon and Emancipatory Social Theory. A View from the Wretched. Boston: Brill, pp. 217-230.

Nürnberger, Marianne. (2015 (2001)) Tanz/Ritual. Integrität und das Fremde. Habilitationsschrift. Wien: Universität Wien, Marianne Nürnberger.

Oliver, Kelly. (2003) Alienation and Its Double; or, The Secretion of Race // Bernasconi, Robert; Cook, Sybol. (Eds.) Race and Racism in Continental Philosophy. Bloomington: Indiana University Press, pp. 176-195.

Sankar, Pamela; Cho, Mildred K.; Mountain, Joanna. (2007) Race and ethnicity in genetic research // American Journal of Medical Genetics. Part A 143A (9). pp. 961-970.

Šuvajevs, Igors. (2019) Rūpes par dvēseli. Vērtību likteñi. Rīga: Zvaigzne.

Zack, Naomi. (1998) Thinking about Race. Belmont: Wadsworth Publishing Company.

Zack, Naomi. (2018) Philosophy of Race. New York: Springer International Publishing; Palgrave Macmillan.

Žižek, Slavoj. (2009) Violence. London: Profile Books. 